\title{
O PERDÃO E SUA POSSIBILIDADE NA PERSPECTIVA DA VONTADE DE PODER
}

\author{
FORGIVENESS AND ITS POSSIBILITY IN THE \\ PERSPECTIVE OF THE WILL TO POWER
}

Oswaldo Giacóia Junior ${ }^{1}$

Recebido em: 15/12/2016

Aprovado em: 30/07/2017

1 Professor Titular do Departamento de Filosofia da Unicamp desde 2013.

Graduado em Filosofia pela Pontifícia Universidade Católica de São Paulo (1976), em Direito pela Faculdade de Direito da Universidade de São Paulo (1976). Mestre em Filosofia pela Pontifícia Universidade Católica de São Paulo (1983) e Doutor em Filosofia pela Freie Universität Berlin (1988). Pós doutorado pela Freie Universität Berlin (93-94), Viena (97-98) e Lecce (2005-2006).

Atualmente é professor Titular do Departamento de Filosofia-IFCH da Universidade Estadual de Campinas. Sua pesquisa concentra-se na área de Filosofia Moderna e Contemporânea, com ênfase em História da Filosofia, Ética e Filosofia do Direito, ocupando-se de temas como: teoria da cultura, ética pura e aplicada, filosofia do direito, filosofia social, política e da história, filosofia clássica francesa e alemã, especialmente com as obras de Augusto Comte, Arthur Schopenhauer e Friedrich Nietzsche. 


\section{Introdução}

No presente trabalho, pretendo apresentar uma interpretação do perdão e sua possibilidade no âmbito do pensamento de Friedrich Nietzsche. Este pode ser caracterizado como uma filosofia das vontades de poder. Vontade de poder, por sua vez, é um termo tão equívoco quanto o Ser de Aristóteles, e pode ser reconhecido numa infinita variedade de formas e modificações, desde as modalidades inferiores mais grosseiras, até as mais refinadas e sublimes. A filosofia das vontades de poder, enquanto vontade de criação de mundos, é ela mesma vontade de poder, impulso de criação e transfiguração:

"Mas esta é uma história antiga, eterna história: o que ocorreu então com os estóicos sucede ainda hoje, tão logo uma filosofia começa a acreditar em si mesma. Ela sempre cria o mundo à sua imagem, não consegue evita-lo; filosofia é esse impulso tirânico mesmo, a mais espiritual vontade de poder, de 'criação do mundo', de causa prima." 2

Nesse sentido, o talento filosófico está essencialmente ligado a um sofisticado sensorium ou aptidão para a identificação, diferenciação e mensuração de graus de poder num universo constituído por relações entre forças, relações estas que são sempre cambiantes, que estão em fluxo permanente, alterando posições de domínio e sujeição, revertendo-as, bem como modificando suas configurações gerais ou complexivas. A história da cultura deixa-se construir como um diagnóstico e como uma hermenêutica dessas relações e de suas transformações no curso do tempo, do vir-a-ser. Nela nada há de fixo, estável, definido, pois definível é apenas aquilo que não tem história - e não há que não seja histórico. ${ }^{3}$

Desse modo, também uma análise do perdão deve ser tentada no elemento de fluidez dos sentidos, que caracteriza o pensamento de Nietzsche, no interior do qual, se a forma é cambiante, o sentido ainda o é mais, pois sentidos são funções de interpretantes, e, com isso, interpretações de relações de força, de configurações de domínio, ou seja expressões de uma determinada ordenação histórica de graus de poder (Rangordnung), para decifração e diagnóstico

\footnotetext{
${ }^{2}$ Nietzsche, F. Além de Bem e Mal. Aforismo 9. Trad. Paulo César de Souza. São Paulo: Companhia das Letras, 2005, p. 15.

${ }^{3}$ Cf. Nietzsche, F. Para a Genealogia da Moral, terceira dissertação, aforismo 13.
} 
da qual requer-se, de parte do filósofo um especial sentido histórico, adestrado na fina e justa arte da graduação.

I - Perdão, Memória e Esquecimento

O verbo perdoar deriva do latim medieval perdonare, que, por sua vez, remete ao latim clássico condonare, por substituição do prefixo e com o significado de não tomar em consideração o mal recebido de outrem, renunciando a propósitos de vingança, de punição, a qualquer possível desforra e revanche, e anulando em si mesmo todo ressentimento voltado contra o autor da ofensa ou do dano. Nesse sentido, portanto, perdoar corresponde literalmente ao verbo alemão vergeben, em estreita relação com o verbo verzeihen, suas três acepções principais: versagen: 'recusar, falhar, não servir' abschlagen' (A), 'sich einer sache versagen, verzichten, aufgeben: renunciar, declinar, desistir (B); ' 'aufwiedergutmachung verzichten': perdoar, desculpar (C),

Nessas acepções, renunciar, desistir, desculpar, perdoar, não mais arrastar consigo ou atrás de si estão ligadas também a dividir, repartir, presentear, dar livre curso, gratificar, renunciar à retribuição em igual medida daquilo que foi dado (geben, gegeben) a alguém como dano ou ofensa. Já etimologicamente, portanto, fica assegurado o vínculo essencial entre perdão e condenação. Perdoar significa, em sentido etimológico e originário, não condenar, e, com isso, renunciar ao revide, a dar de volta o que foi infligido a alguém, de modo que - desde sempre - perdoar implica em superar o espírito do ressentimento. Para tanto, é necessário esquecer o sofrimento que resulta de uma vivência negativa, ou seja, daquela vivência que causa sofrimento. É necessário, portanto, uma força psíquica de assimilação, capaz de metabolizar uma experiência ou vivência que se congela na memória.

Perdoar é uma ação positiva, uma virtus: relevar, e tem como pressuposto a assimilação e metabolização de uma experiência negativa, uma capacidade ativa de incorporação e superação, uma força plástica e transformadora de integração no continuum da vida psíquica, que torna possível que vivências, especialmente negativas, sejam concluídas (fertig werden, levadas a cabo, que seja possível acabar com elas. Ora, essa capacidade exige uma força de assimilação de natureza semelhante à do esquecimento: ela supõe que a memória não seja infectada, entravada e tornada dispéptica por uma indigestão das experiências vividas. O que significa dizer que essa força plástica tem a mesma natureza da força ativa do esquecimento. Tanto poder lembrar-se quanto po- 
der esquecer são, nesses termos, provas de força, expressões de poder, não de incapacidade ou de impossibilidade: o contrário de um não poder lembrar-se, bem como de um não poder esquecer.

Do mesmo modo, perdoar é também poder, e implica em passar por cima da ofensa e do prejuízo; essa superação, por sua vez, exige ou pressupõe um poder fazer ou um doar superior à retribuição e à revanche: um dar ou fazer congelado em resposta ou reação àquilo que nos foi feito. Nota-se, desde logo, que a possibilidade do perdão implica não apenas o esquecimento da ofensa, mas também a superação da retaliação, ou seja um dar gratuito, dissipatório, perdulário, a renúncia à retaliação - vale dizer, em termos econômicos, uma perspectiva de plenitude, impossível a partir do vértice da indigência.

É nesse horizonte que pode ser colocada, em termos de Nietzsche, a antiga oposição teológica entre a lei e a graça. A lei, em virtude de sua própria forma, não pode renunciar ao vínculo necessário entre um fazer (ou um agir dado, geben) e sua consequência jurídica - a pena, sempre compreendida em termos de compensação, retribuição, revanche ou vingança. A lógica jurídica é essencialmente econômica, uma vez que deriva da matriz jurídico-econômica do débito e do crédito; de modo que, tudo o que se baseia na lei obedece esse mesmo princípio de retribuição. Do ponto de vista legal, não existe um livredar - um perdonare - mas sempre um revide, uma vinculação imputativa e necessária, que duplica a relação entre causa e efeito - ou seja, a relação entre um fazer, um fato dado, e a resposta jurídico-legal correspondente a esse dar ou fazer, fundada numa proporção fixada pela lei. A lei, portanto, nunca perdoa, ela só conhece a punição, ela compensa, re-equilibra as relações entre a ofensa e o castigo. Do ponto de vista da justiça da lei, não pode existir, portanto, nenhum perdão, no sentido originário da palavra, pois a lei consiste precisamente nesse vínculo entre o ato, o dado, o feito e sua consequência, a saber a punição. Do ponto de vista da lei, o indulto ou a graça é sempre e apenas uma prerrogativa decorrente, uma subrogação do poder de punir.

Sendo assim, o perdão, em sentido positivo, e não meramente reativo, como abstenção da punição, necessariamente transcende a lógica da lei, escapa à ótica legal. Ora, em que consiste esse ultrapassamento? Em termos de Nietzsche, numa singular relação de força: ser capaz de não revidar é o mesmo que ser capaz de não se vingar. Para tanto, o pressuposto necessário consiste num plus de força (ser capaz de não fazer, uma positividade do negativo), que tornar pos- 
sível renunciar à vingança, e considerar a ofensa de um ponto de vista sobranceiro e imparcial - objetivo -, a partir do qual o concernimento particular e seus ímpetos naturais de retribuição - inevitáveis em primeira instância - teriam que ser suficientemente moderados, refreados e postos sob controle por um excedente de força, que se recusa a esgotar-se na reação imediata, ressentida.

Para poder perdoar é necessário, antes de qualquer outra coisa, ser capaz de assimilar golpes, de transformar vivências, precisamente do que Nietzsche denomina de força plástica, metabólica: uma potência de transformação, que não pode ser compreendida sem uma referência à memória e esquecimento. Com efeito, se a memória é a possibilidade humana de colocar em suspenso a potência do esquecimento - entendida como condição fisiológica de saúde -, a memória pode ensejar também, com esse bloqueio, uma dispepsia das vivências, uma inibição da faculdade de assimilação e transformação, um travamento semelhante à dispepsia e intoxicação orgânica. Essa paralisia é sintoma de uma fragilidade orgânica e anímica - já que, do ponto de vista de Nietzsche, não existe separação entre fisiologia e psicologia, entre somático e psíquico, não existe dualismo substancial.

Se perdoar é não condenar, é dar de graça, no sentido de não retribuir, então para que haja possibilidade de perdão é necessário que a ofensa tenha sido assimilada, metabolizada, integrada, de tal forma, que ela não seja mais sentida, não seja ressentida. Que ela passe, segundo a ordem do tempo. O que vale dizer, que possa ser eficazmente esquecida. Para tanto, é necessário que se pressuponha uma forte, hígida capacidade de assimilação, de metabolismo, para a qual o poder esquecer possa diferenciar-se de um não poder lembrar.

A dialética entre esquecimento e memória, ambos pensados como forças ativas, é, para Nietzsche, constitutiva do processo de hominização; e se o homem é um animal doente, o animal não fixado e estabilizado, é porque essa relação é sempre tensa, problemática; ela é também o elemento discriminante entre saúde e doença, entre presente d futuro do humano na história.

"Esquecer não é uma simples vis inertiae como crêem os superficiais, mas uma força inibidora, ativa, positiva no mais rigoroso sentido, graças à qual o que é por nós experimentado, vivenciado, em nós acolhido, não' penetra mais em nossa consciência, no estado de digestão (ao qual poderíamos chamar "assimilação psíquica"), do que todo o multiforme processo da nossa nutrição corporal ou "assimilação físi- 
ca". Fechar temporariamente as portas e as janelas da consciência; permanecer imperturbado pelo barulho e a luta do nosso submundo de órgãos serviçais a cooperar e divergir; um pouco de sossego, um pouco de tabula rasa da consciência, para que novamente haja lugar para o novo, sobretudo para as funções e os funcionários mais nobres, para o reger, prever, predeterminar(pois nosso organismo é disposto hierarquicamente) - eis a utilidade do esquecimento, ativo, como disse, espécie de guardião da porta, de zelador da ordem psíquica, da paz, da etiqueta: com o que logo se vê que não poderia haver felicidade, jovialidade, esperança, orgulho, presente, sem o esquecimento. O homem no qual esse aparelho inibidor é danificado e deixa de funcionar pode ser comparado (e não só comparado) a um dispéptico - de nada consegue "dar conta"... Precisamente esse animal que necessita esquecer, no qual o esquecer é uma força, uma forma de saúde forte, desenvolveu em si uma faculdade oposta, uma memória, com cujo auxílio o esquecimento é suspenso em determinados casos nos casos em que se deve prometer: não sendo um simples não-mais-poder-livrar-se da impressão uma vez recebida, não a simples indigestão da palavra uma vez empenhada, da qual não conseguimos dar conta, mas sim um ativo não-mais-querer-livrar-se, um prosseguir-querendo o já querido, uma verdadeira memória da vontade: de modo que entre o primitivo "quero", "farei", e a verdadeira descarga da vontade, seu ato, todo um mundo de novas e estranhas coisas, circunstâncias, mesmo atos de vontade, pode ser resolutamente interposto, sem que assim se rompa esta longa cadeia do querer." 4

É a uma força plástica e modeladora do esquecimento que se deve a saúde e a abertura para um horizonte de presente. Um caso paradigmático, para Nietzsche, é o de Mirabeau que, "preso, não poderia reagir às adversidades impostas a ele, mas que também não apresentava sintomas de ressentimento simplesmente porque esquecia as adversidades sofridas. Uma força desconhecida do o homem do ressentimento, pois, além de não poder reagir, ele não consegue lidar com os seus dissabores. Assim, termina por acumular em si todo veneno que corresponde à sede de vingança, ódio e rancor, o que torna a sua memória uma "ferida aberta" (EH, Por que sou tão sábio, 6) de tal

${ }^{4}$ Nietzsche, F. Genealogia da Moral. II, 1. Trad. Paulo César de Souza. São Paulo: Companhia das Letras, 1999, p. xxxx. 
forma que o passado o impede de viver efetivamente e desfrutar do presente". ${ }^{5}$

\section{O Perdão e a Psicologia do Ressentimento}

Essa questão nos remete à essência do ressentimento. Portanto, para poder superar o ressentimento em si mesmo, é necessário que o doente seja capaz de, como a serpente, 'trocar de pele', estar em condições de se converter no contrário de si mesmo. Pois livrar-se do ressentimento, mantendo-o abaixo de si, significa retornar à saúde, se é verdade que, como afirmamos há pouco, a própria doença é ressentimento. Esse nec plus ultra de auto superação se faz a partir da vivência do ressentimento sob o ângulo da potência.

Para se poder compreender o problema assim formulado, é necessário retomar aquele antagonismo entre dois tipos de doentes e sofredores, com que iniciamos nosso trabalho, a saber: aquela distinção capital entre excedente de força e indigência, que faz a diferença entre o saudável e o patológico. Agora, porém, torna-se necessário também que o percebamos como que reduplicado, segundo uma perspectiva diversa da anterior.

Não se trata mais, agora, de opor absolutamente o saudável ao doentio, mas de operar no interior de duas modalidades diversas de patologia: por um lado, aquela do doente incurável e, por outro lado, aquela do enfermo que pode retornar a si e partir para uma nova saúde, tendo a grave enfermidade como condição.

Essa diferença está ligada ao modo como o doente ainda pode lidar com o próprio ressentimento. Minado pela bílis infecciosa da vingança, debilita-se, no sofredor o fôlego que ainda restava para a força defensiva, capaz de repelir o que prejudica - aquele 'agressivo instinto de cura e resistência', que é também energia de assimilação produtiva e restauração.

Seqüestrada pelo ressentimento, a doença se torna fraqueza num sentido particularmente perigoso: em razão da debilidade, o ressentimento invade e domina a consciência do sofredor, transtornando o metabolismo psicológico que regula a alternância entre percepção, esquecimento e memória das vivências, sobretudo o processo de assimilação dos traços de lembranças negativas.

${ }^{5}$ Paschoal, A. E. A Superação do Ressentimento na Filosofia de Nietzsche. Estudos Nietzsche, Curitiba, v. 3, n. 2, p. 183-206, jul./dez. 2012, aqui p. 194. 
Uma vez minada a força plástica do esquecimento, o sofredor se torna incuravelmente ressentido, porque sua consciência é pervadida pelos traços das lembranças aflitivas, que atraem como imã a energia dos outros estados psíquicos.

"Não se sabe nada rechaçar, de nada se desvencilhar, de nada dar conta - tudo fere. A proximidade de homem e coisa molesta, as vivências calam fundo demais, a lembrança é uma ferida supurante" ${ }^{6}$ Nesse caso, o ressentimento constitui $a$ doença propriamente dita, aquilo que mantém obstruído o processo de assimilação psíquica das vivências. Em tais condições, a dor não pode ser a grande dor, que liberta o espírito, fazendo com que ele se eleve acima de si mesmo, supere a intoxicação pelas lembranças mórbidas, e descortine novos horizontes de visão e poder.

Quanto mais sofre, tanto mais anseia o sofredor por livrar-se desse fardo. Seu desejo mais ardente é o de narcotizar a consciência sofredora. Para tanto, a via mais rápida é a descarga internalizada de tônicos afetos vingativos, numa reação incendiária, que permanece a nível da imaginação, consumindo todas os afetos numa forma pervertida, "certamente a forma mais nociva de reação"7, escreve Nietzsche. Essa é a pior escapatória porque não constitui nenhuma saída efetiva, senão que produz um curto circuito paralizante, extinguindo rapidamente quase todas as energias nervosas. Essa devastação internalizada das próprias forças tragadas pela sede de vingança promove justamente o contrário da cura.

Esta, só poderia ser obtida pelo esquecimento. Porém a vingança imaginária mantém aceso o desejo incessante de encontrar culpados e puni-los, o que anestesia a consciência do sofrimento, é verdade; mas sendo necessário manter a memória da ferida, a sede de vingança tem de sacrificar, em sua própria fogueira, todas as outras energias dessa alma envenenada. Desse modo, o risco da contaminação pela vingança é o maior dos perigos para o sofredor. $\mathrm{O}$ ressentimento só alivia a dor, na medida em que infecciona a chaga.

E, no entanto, é no interior desse circuito patológico que se pode vislumbrar como o ressentimento pode fornecer seu próprio contra-veneno: pela desativação do desejo de vingança. Essa é justamente a terapia prescrita pelo psicólogo Nietzsche contra confisco da doença pelo ressentimento:

\footnotetext{
${ }^{6}$ Ibid.

${ }^{7}$ Ibid.
} 
"Contra isso o doente tem apenas um grande remédio - eu o chamo de fatalismo russo, aquele fatalismo sem revolta, com o qual o soldado russo para quem a campanha torna-se muito dura finalmente deita-se na neve. Absolutamente nada mais em si aceitar, acolher, engolir - não mais reagir absolutamente... A grande sensatez desse fatalismo, que nem sempre é apenas coragem para a morte, mas conservação da vida nas circunstâncias vitais mais perigosas, é a diminuição do metabolismo, seu retardamento, uma espécie de vontade de hibernação. Alguns passos adiante nesta lógica e temos o faquir que durante semanas dorme em um túmulo... Porque nos consumiríamos muito rapidamente se reagíssemos, não reagimos mais: esta é a lógica." ${ }^{8}$

Para tornar-se capaz disso, porém, é necessário que, no enfermo, ainda não tenham sido inteiramente extintos aqueles mananciais de forças plásticas e restauradoras que Nietzsche identifica com os instintos curativos de resistência e assimilação ativa. É necessário, sobretudo, que o enfermo não tenha sucumbido inteiramente à infecção; a saber, que a sede de vingança ainda não tenha se tornado irresistível, e tomado conta dele. Para aquele fatalismo russo na enfermidade, é necessário que, no doente, ainda se mantenha acesa uma pequena chama de auto-domínio, que o torna capaz de voltar a si e convalescer.

Se, em certo sentido, a própria doença é ressentimento, precisamente isso é também, e paradoxalmente, "o proibido em si para o doente - seu mal: infelizmente também sua mais natural inclinação." ${ }^{9}$ Como decifrar tais enigmas psicológicos sem incorrer na mais grosseiras contradições?

Para responder tais questões, temos que nos valer de uma contraposição entre dois tipos de doença e de sofrimento e, por conseguinte, dois modos possíveis de viver o ressentimento; a rigor, com ajuda do aforismo 370 de $A$ Gaia Ciência, poderíamos distinguir até mesmo dois tipos antagônicos de ressentimento.

Há pouco, quando examinamos, o prefácio de A Gaia Ciência, vimos que Nietzsche se valera de uma imagem semelhante, reportando dois tipos de filosofia a dois tipos de pessoa: para uma delas, para as doentias e carentes, são as necessidades que filosofam; para as outras, para as saudáveis e íntegras, são as forças transbordantes e o sentimento de plenitude que se transfiguram em

\footnotetext{
${ }^{8} \mathrm{Ibid}$.

9 Id. p. 20 s.
} 
filosofia. Veremos que, no caso presente, antagonismo análogo se reproduz no interior do pólo doentio e sofredor.

"Mas existem dois tipos de sofredores, os que sofrem de abundância de vida, que querem uma arte dionisíaca e também uma visão e compreensão trágica da vida - e depois os que sofrem de empobrecimento de vida, que buscam silêncio, quietude, mar liso, redenção de si mediante a arte e o conhecimento, ou a embriaguez, o entorpecimento, a convulsão, a loucura." 10

A um desses tipos de sofredor corresponde o doente exaurido, prisioneiro de um ressentimento consumptivo, brotado da fraqueza, da incapacidade de reagir, que consome na chama ardente da vingança a inteira gama de sentimentos e afetos. No outro caso, em que o doente ainda mantém a posse de si mesmo, portanto, em que, mesmo sob a pressão da doença, "se pressupõe uma natureza rica", com um excedente de força e instinto de cura, o ressentimento pode ser vivido como um sentimento entre outros; ou, como o diz o psicólogo Nietzsche, como "um sentimento supérfluo". ${ }^{11}$

Nesse caso, e somente nele, o ressentimento ainda pode voltar-se contra $s i$, transfigurar-se naquela dietética e arte curativa figurada pelo fatalismo russo. Podemos tornar clara essa reviravolta dialética recorrendo à profusão de imagens e metáforas mobilizadas por Nietzsche na passagem correspondente a essa figura.

O conjunto das imagens visa, desde o início, um capcioso efeito de paradoxo, para desestabilizar certezas: as expressões são, à primeira vista, de pura passividade, mesmo letargia, renúncia; não há aqui apenas alusão a uma atmosfera propícia ao ascetismo. Sem véus, os próprios ideais ascéticos são diretamente convocados como expediente para prevenir e evitar a reação vingativa. Eles comparecem sob a forma da 'diminuição e retardamento do metabolismo', de 'uma espécie de vontade de hibernação'; estratégias de destonificação de afetos perigosos. ${ }^{12}$

\footnotetext{
${ }^{10}$ Nietzsche, F. A Gaia Ciência. Aforismo 370, op. cit. p. 272s.

11 Ibid.

${ }^{12}$ Entretanto, é justamente por causa dessa equivocidade e proximidade aparente que toda precaução deve ser empregada para distinguir entre, por um lado, a renúncia entendida como um ativo abster-se de uma reação consumptiva (a continência) - que é sintoma de força -, e, por outro lado, a impotência para resistir à vingança, o não poder evitar a dissipatória reação ressentida, que leva à vontade de narcose, à anestesia da vontade - sintoma de debilidade e morbidez.
} 
Não deixa de ser enaltecida sequer certa morbidez, alusiva ao sono fúnebre. "Alguns passos adiante nesta lógica e temos o faquir que durante semanas dorme em um túmulo..." ${ }^{13} \mathrm{E}$, contudo, não se trata aqui apenas do que Nietzsche denomina "coragem para a morte, mas conservação da vida nas circunstâncias mais perigosas". ${ }^{14}$

Tais circunstâncias são particularmente perigosas porque, nesse caso, a vulnerabilidade do doente é como que potencializada. O desencadeamento dos afetos tônicos brotados do ressentimento, tais como a super excitada irritabilidade nervosa, a doentia vulnerabilidade, a ânsia e o desejo impotente de vingança - podem levar ao rápido esgotamento daquele doente incapaz de reagir, cujas energias nervosas são tragadas na voragem das lembranças negativas, ou contagiadas como feridas psíquicas purulentas.

Nessas circunstâncias, como foi dito anteriormente, a descarga imaginária dos afetos vingativos, em virtude de sua tonicidade e vigor, serve como narcótico para o sofrimento; entretanto, estando inibida a força plástica do esquecimento, não apenas permanece atuante a causa da dor, senão também que é re-investida a cada nova vivência, uma vez que o ressentimento se propaga por contágio. Portanto, aquela descarga interiorizada como narcótico não faz mais que extenuar. Esse tipo de reação consome, torna ainda mais fraco o doente, enredando-o mais profundamente em sua debilidade. É por causa disso que, de acordo com Nietzsche, o ressentimento é, para o doente, aquilo que é proibido em si.

Cabe aqui observar que, nesse contexto da clínica fisio-psicológica nietzscheana, que a transição do físico ao psíquico é sempre pensada em dupla direção. A condição somática de doença produz, como efeito, um esmorecimento do instinto de cura e resistência; o que é propício, por sua vez, à emergência dos afetos ligados ao ressentimento, como a hiper irritação, a vulnerabilidade às lembranças, o embotamento da capacidade de esquecimento e o desejo permanente de vingança. Inversamente, a descaga desses afetos gera efeitos de ordem física, como "rápido consumo de energia nervosa, um aumento doentio de secreções prejudiciais, de bílis no estômago, por exemplo" ${ }^{15}$

\footnotetext{
${ }^{13}$ Nietzsche, F. Ecce Homo, op. cit. p. 30

14 Ibid.

15 lbid.
} 
Nesse mesmo ductus de argumentação, ao mencionar aprovativamente o regime de higiene budista dos afetos, Nietzsche interpreta em chave fisiológica a dietética espiritual de Buda: como bom fisiólogo, este teria adivinhado a necessidade de proteger os seus doentes contra a mais natural inclinação dos fisiologicamente extenuados, ou seja, o ressentimento. A medicação prescrita por ele consistia em purgar da alma os afetos vingativos, de maneira que o bom resultado da higiene psíquica estava ligado à "eficácia da vitória sobre o ressentimento: libertar a alma dele - primeiro passo para a convalescença. ${ }^{16}$

A partir de tais exemplos, podemos distinguir dois modos de viver o ressentimento e seus estados, bem como dois tipos opostos de ressentimento: o ressentimento brotado da impotência, que se caracteriza como aquele incapaz de evitar a forma mais grosseira e deletéria de reação. Esse é o ressentimento que envenena e esgota rapidamente a energia nervosa, tornando o doente incapaz de resistir, de se desvencilhar de suas lembranças. Nesse caso, falta o autodomínio, que torna possível ao doente não se render ao contágio causado pelo desejo permanente de vingança. Aqui, não há vitória sobre o ressentimento, a alma é impotente para se libertar da vingança.

No outro tipo de sofrimento, também são vividos os afetos do ressentimento, porém não unicamente sob a forma infecciosa da vingança, com perda da capacidade de controle sobre as reações. Aqui vigora a lógica prudencial, cuja expressão terapêutica determina a dieta nietzscheana para a convalescença: "Porque nos consumiríamos muito rapidamente se reagíssemos, não reagimos mais: esta é a lógica" ${ }^{17}$

Essa lógica traz consigo a confirmação de que a tensão e o contraste entre debilidade e força é retomado e retrabalhado por Nietzsche, agora numa perspectiva ainda mais interior: num um só e mesmo doente, na alternância de seus estados, pode-se discernir entre excedente de força e fraqueza, no próprio intercurso da enfermidade.

Referindo-se à disciplina que impusera aos sentimentos vingativos em seus piores e mais graves momentos de sofrimento, escreve Nietzsche: "Nos períodos de décadence eu os proibi a mim por prejudiciais: tão logo a vida voltou a ser rica e orgulhosa o bastante para isso, eu os proibi como abaixo de mim.

\footnotetext{
${ }^{16}$ Id. p. 31.

17 Id. p. 30.
} 
Aquele 'fatalismo russo' de que falei mostrou-se em mim no fato de que durante anos apeguei-me tenazmente a situações, paragens, moradas, companhias quase insuportáveis; uma vez que me haviam sido dispostas pelo acaso - era melhor do que mudá-las, do que sentí-las como mutáveis - do que revoltar-se contra elas." 18

Quando o pensamento se encontra extenuado sob a pressão de grave enfermidade, reagir, sob a forma da descarga de afetos vingativos, seria propriamente dissipar-se. Por essa razão, a sabedoria do fatalismo os proíbe como nocivos. Em seguida, quando as energias do paciente estão um pouco mais revigoradas, eles podem ser sentidos, porém proibidos como supérfluos, isto é, como superados pelo doente. Sentir como abaixo de si o desejo de vingança constitui, a ver de Nietzsche, quase que a prova inquestionável do retorno da força, o mais claro sintoma da convalescença e da transição para uma nova saúde.

Para libertar a alma do ressentimento faz-se, pois, necessário, poder renunciar ao desejo de vingança, ou seja, não se revoltar contra aquilo que incomoda, irrita, fere; não permitir que aquilo a que se está exposto e vulnerável também envenene. Para a fisiologia de Nietzsche, a eficácia do fatalismo russo consiste em que, com ele, supera-se o ressentimento, pela mais curiosa das medicações: o amor fati. “Tomar a si mesmo como um fado, não se querer 'diferente' - em tais condições isso é a grande sensatez mesma." ${ }^{19}$

Não se revoltar contra a adversidade significa aqui acolhimento, mesmo daquilo que se opõe a nós e nos faz sofrer; para evitar o rancor que envenena e nos faz amaldiçoar a existência, é necessário poder não apenas resignar-se, mas acolher o adverso como não transformável, pelo menos durante aqueles estados de debilidade e consumpção das energias vitais, quando mais somos susceptíveis aos afetos vingativos.

Aqui, precisamente, é necessário demonstrar a resistência instintiva e a tenacidade do faquir; tornar afirmativa e positiva a inação, que permite conservar a vida, naquele tênue limiar em que ela ameaçava expirar. Para o doente extenuado, o ressentimento seria, nesses casos, a mais imediata e irresistível, mas também a mais funesta das tentações. Porisso mesmo, é preciso evitá-lo como nocivo; um passo mais adiante e poder renunciar a ele, enquanto senti-

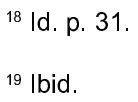


mento supérfluo, constitui clara demonstração de que somos convalescentes, de que já nos tornamos de novo fortes o suficiente para dominá-lo, de um plus de força que refoge à decadência, à anarquia dos impulsos, à consunção. Convalecer significa, antes de tudo, poder resistir, poder não reagir, reservar-se, evitar a tentação quase irresistível do ressentimento, considerado enquanto descarga interiorizada de afetos tônicos, com objetivo de anestesiar a dor pela intensificação do sofrimento, transfigurado pela ilusão de plenitude e satisfação.

\section{III - O Perdão, a Lei e a Graça}

Num texto intitulado Para uma Crítica da Violência, Walter Benjamin considera que somente uma justiça divina - que precede o ato para que este não se realize - pode perdoar e libertar de toda culpa. A jurisdição da lei pelo contrário, é antecipação condenatória, nela o fundamento da obediência é apenas temor da punição, pois a lei é produzida em vista do juízo e da inculpação - mesmo que o juízo se pronuncie finalmente pela absolvição. Pois nele permanece válido o pressuposto de que o mandamento permanece comensurável com o ato, razão pela qual do mandamento pode ser derivado ou deduzido um juízo aplicável ao ato, portanto, sob a égide da lei, que, pela imputação, pressupõe e vive justamente da representação do mandamento como medida do ato. Nesse sentido, o juízo é reprodução da violência mítica e sangrenta, a perpetuação da culpa que elide a perspectiva da inocência e do perdão.

Não é possível deixar de discernir nessa passagem uma argumentação análoga àquela que podemos encontrar na dialética entre a justificação, o pecado e a lei, tal como tematizada pelo apóstolo Paulo na Epítola aos Romanos:

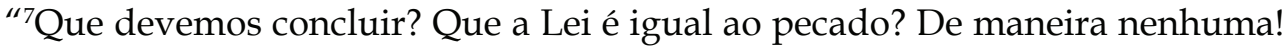
Mas, eu não conheci o pecado, senão por meio da Lei. Assim, não teria conhecido a cobiça, se a Lei não dissesse: Não cobiçarás. ${ }^{8} \mathrm{O}$ pecado aproveitou-se da ocasião dada pelo mandamento e provocou em mim toda a espécie de cobiça. É que, sem a lei, o pecado é coisa morta. ${ }^{9} \mathrm{Eu}$, sem a lei, estava vivo outrora. Mas, ao chegar o mandamento, ganhou vida o pecado ${ }^{10} \mathrm{e}$ eu morri. E deparei-me com isto: o mandamento que me devia levar à vida, esse mesmo levou-me à morte. ${ }^{11}$ É que o pecado, aproveitando-se da ocasião dada pelo mandamento, seduziu-me e deu-me a morte, por meio dele. ${ }^{12}$ Por conseguinte, a Lei é santa e o mandamento é santo, justo e bom. ${ }^{13}$ Será então que aquilo que é bom se 
transformou em morte para mim? De maneira nenhuma! O pecado é que, para se manifestar como pecado, se serviu do que é bom e foi causa de morte para mim. Foi por meio do mandamento que o pecado ganhou uma extrema força pecaminosa." 20 .

Já para Nietzsche, uma efetiva espiritualização da potência teria sido realmente alcançada quando a sociedade fosse suficientemente forte para superar a perspectiva da lei e do juízo, e, por exemplo, poder não fazer mais caso de crime e castigo. "Não é inconcebível uma sociedade com tal consciência de poder que permitisse o seu mais nobre luxo: deixar impunes seus ofensores: 'Que me importam meus parasitas?, diria ela. 'Eles podem viver e prosperar - sou forte o bastante para isso!'... A justiça, que iniciou com 'tudo é resgatável, tudo tem que ser pago', termina por fazer vista grossa e deixar escapar os insolventes -." 21

Apesar da barbárie e de todo 'idiotismo' de sua pré-história, a genealogia do sentimento de justiça pode apontar, como resultado tardio, a gestação de uma 'boa vontade', de um 'espírito muito bom', como predicados e virtudes do 'homem justo'. São essas virtudes que animam a resconstituição de mais um percurso de auto-superação, que se desdobra a partir dessas virtudes, e que culminam na superação da justiça pela graça. Penso que essa figura correponde à dissolução e à superação do vínculo mítico ancestral entre direito, justiça e violência, a partir de uma intensificação do sentimento de poder, que o altera substancialmente, transfigurando-o por sublimação.

"Se crescem o poder e a consciência de si de uma comunidade, tornase mais suave o direito penal; se há enfraquecimento dessa comunidade, e ela corre grave perigo, formas mais duras desse direito voltam a se manifestar. $\mathrm{O}$ 'credor' se torna sempre mais humano, na medida em que se torna mais rico; $\mathrm{e}$ o quanto de injúria ele pode suportar sem sofrer é, por fim, a própria medida de sua riqueza. A auto-supressão da justiça: sabemos com que belo nome ela se apresenta - graça; ela permanece, como é óbvio, privilégio do poderoso, ou melhor, o seu 'além do direito'." 22

Essa (auto) superação da justiça da lei pela graça encontra um paralelo fecundo em outra figura de auto-superação: a transfiguração da força em bele-

${ }^{20}$ Epístola aos Romanos, VII, 7-13.

21 GM II, 10. Trad. De Paulo César de Souza, p. 62.

22 lbid. 
za, já presente em Assim Falou Zaratustra, assim como a sublimação da crueldade em cultura, tematizada desde os escritos do jovem Nietzsche, fio vermelho que, desde Humano, Demasiado Humano tece a trama de sua filosofia. Evidentemente, trata-se sempre de vontade de poder, mas sobretudo de sua transfiguração, de sua elevação a uma esfera cada vez mais efetivamente poderosa e consciente de poder, o que significa, ao mesmo tempo, que, em correspondência com essa consciência, prescinde da força bruta, da violência mítica.

O capítulo sobre Os Sublimes, do segundo livro de Assim Falou Zaratustra é paradigmático a respeito dessa transformação sublimadora. Sublimes são penitentes e heróis das mais prodigiosas façanhas do espírito. No entanto, a seriedade de sua altivez demonstra ainda a fixação num estado ainda primitivo, da força, porque ainda zelosa, ciumenta, grave, sem leveza, prodigalidade, beleza - isto é, transbordamento de força. "Ele dominou monstros, ele decifrou enigmas: mas ele ainda deveria também redimir seus monstros e enigmas, deveria ainda transformá-los em crianças divinas. Ainda não ensinou seu conhecimento a rir; sua paixão corrente ainda não se acalmou na beleza... $\mathrm{O}$ braço deitado sobre a cabeça: assim deveria repousar o herói, ele deveria superar também ainda seu repouso. Mas justamente ao herói o mais difícil é o belo de todas as coisas. Inatingível é o belo para toda vontade impetuosa. Um pouco mais, um pouco menos: justamente isso é aqui muito, isso é aqui o maior. Estar de pé com os músculos relaxados, com a vontade desprendida: isso é o mais difícil de tudo para todos vós, vós os sublimes! Quando o poder (Macht) torna-se clemente (gnädig) e vem cá para baixo, para o visível, a esse vir-cá-para-baixo eu chamo beleza". ${ }^{23}$

Nesse parágrafo, desenvolve-se uma curiosa e implícita dialética entre acima e abaixo, elevação (sublime) e supressão (heben, aufheben), denotando que a beleza é a suprassunção do que, no herói, ainda é gravidade, zelo, seriedade. Essa auto-supressão da gravidade a transfigura ou redime (esteticamente) em beleza. Os heróis do espírito e do corpo ainda não deixaram repousar o braço sobre a cabeça, ainda não redimiram o próprio cansaço e a necessidade de repouso: suas verdades são horríveis, eles são ricos somente em presas de caça, em vestimentas dilaceradas, ornados de espinhos terríveis, mas com nenhuma rosa. Ele ainda não foi elevado pelo éter, ainda não desaprendeu sua

${ }^{23}$ Nietzsche, F. Also Sprach Zarathustra (ZA), II, Von den Erhabenen. In: KSA, op. cit. vol. 4, p. 151s. 
vontade heróica, a ponto de tornar-se desprendido de vontade (ein Willenloser).

No caso da justiça, da lei, do direito, do Estado, cuja origem é a violência e a força, a auto-supressão verifica-se sob a forma de uma força de segunda potência, de uma força suficientemente poderosa para ser clemente, dadivosa, graciosa. E isso a tal ponto que sua matéria prima bruta é transfigurada e redimida numa figura sublimada de poder, capaz de renunciar à sua primitiva materialidade e, de clemente tornar-se graciosa, ou seja purificar-se na graça, no duplo sentido teológico e estético. Essa é a lei da auto-supressão a que estão sujeitas as grandes coisas.

É a natureza paradoxal desse hegelianismo negativo que vem à luz na figura do indivíduo soberano, de maneira exemplar; pois nela Nietzsche investiga a história de proveniência da justiça a partir de seu oposto, a saber genealogicamente, a partir da violência, da violentação, do arbítrio, da crueldade. „A justiça provém, segundo Nietzsche, da troca de crueldades, que, com o tempo, exige a regulamentação pelo direito num Estado que, uma vez tendo conquistado para o direito suficiente validez, pode por fim renunciar completamente à crueldade na figura dos castigos, e, com isso, pode mirar sua autêntica justiça.“ ${ }^{24}$

\section{Conclusão}

Se até aqui pudemos sustentar uma relação cerrada entre perdão, legislação e ressentimento, isso não indica que tenhamos atingido a camada mais profunda dessa temática. Esta somente vem à tona quando divisamos o elemento ontológico-existencial de onde deriva genealogicamente o espírito de vingança, e, com ele, toda a perspectiva de culpa e castigo, bem como, e consequentemente, de possibilidade de perdão e redenção. Esse elemento radica na condição finita e temporal da existência humana, bem como na impotência da vontade, que nela tem seu abismo.

Num capítulo de Assim falou Zaratustra, significativamente intitulado: Da Redenção, escreve Nietzsche: “Assim se chama o ranger de dentes e a mais

${ }^{24}$ Stegmaier, W. Hegel, Nietzsche, Heraklit. In: Djuric, M. Simon, J. (Org). Nietzsche und Hegel. Würzburg: Königshausen \& Neumann, 1992, p. 126. Para uma metódica investigação a respeito das diferentes figuras de auto-supressão em Nietzsche, cf. Zittel, C. Selbstaufhebungsfiguren bei Nietzsche. Würzburg: Königshausen \& Neumann, 1995. 
solitária tribulação da vontade. Impotente contra o que está feito - a vontade é um mau espectador para todo passado. A vontade não pode querer para trás: que não possa quebrantar o tempo nem a voracidade do tempo - essa é a mais solitária tribulação da vontade ... 'O que foi, foi' - assim se chama a pedra que [a vontade) não pode remover. E assim ela remove pedras por raiva e por aversão, e vinga-se naquilo que não sente, do mesmo modo que ela, raiva e aversão." 25

Assim, vingança é repugnância e aversão da vontade contra o tempo. Nisso consiste também o essencial da impotência vontade- na impossibilidade de confrontar-se não só com uma dimensão do tempo, com um período ao lado dos outros, mas de suportar aquilo o que o tempo essencialmente confere, dispensa e lega - o passar e o que passou; e, ao legá-lo, ele também já o congela na dimensão de um 'já era' inamovível. O tempo só doa e concede o que ele tem, e ele tem o que ele é - a saber, o decurso, o transcurso, a travessia.

“A vingança é, para Nietzsche, a repugnância da vontade contra o tempo. Isso agora diz: A vingança é a repugnância da vontade contra o decorrer e seu decorrido, contra o tempo e o seu 'era'. A repugnância da vingança dirigese contra o tempo à medida que deixa estar o decorrido ainda apenas enquanto passado, que se congela na rigidez desse algo definitivo... A repugnância da vingança permanece acorrentada a esse 'era'; assim como em todo ódio também se oculta a mais abissal dependência daquilo de que o ódio constantemente no fundo deseja tornar-se independente, o que, porém, nunca pode, e cada vez menos pode, enquanto odeia." 26

A vontade, sem consciência da própria impotência, vinga-se, então, naquilo contra o que se quebranta sua força, contra o que sobre ela prevalece - o inamovível e definitivo, a que se acorrenta mais fortemente, a cada ato de vingança. A repugnância da vontade contra o fluxo do tempo é a outra face da adversidade contra o imutável. Dessa repugnância nasce todo desejo de Alémdo-Mundo, toda necessidade de consolo metafísico.

Por isso Nietzsche pode dizer que amor fati significa amor pelo destino e pela totalidade do existente, sem acréscimo nem subtração - esta é sua fórmula

\footnotetext{
${ }^{25}$ Nietzsche, F. Assim Falou Zaratustra. II: Da Redenção. In: KSA. op. cit. p. 177s.

${ }^{26}$ Heidegger, M. Que Significa Pensar? Trad.Paulo R. Schneider. In: Schneider, P. R. O Outro Pensar. Ijuí: Editora Unijuí, 2005, p.182s.
} 
para uma postura dionisíaca em relação à totalidade da existência. "Uma tal filosofia experimental, como eu a vivo, antecipa até mesmo, a modo de experimento, as possibilidades do niilismo fundamental: sem que com isso fosse dito que ela permaneça em um Não, numa negação, numa vontade de não. Pelo contrário, ela quer, antes, transitar para o inverso disso tudo - para um dionisíaco dizer-sim ao mundo, como ele é, sem subtração, exceção, escolha - ela quer o ciclo eterno, - as mesmas coisas, a mesma lógica e não-lógica dos elos. Estado supremo que um filósofo pode alcançar: postar-se dionisiacamente em face da existência -: minha fórmula para isso é amor fati..." ${ }^{27}$

A finitude infinita traz à luz a extrema impotência da vontade, que consiste, para Nietzsche, em sua aversão para com o (passar do) tempo, com a transitividade do tempo - na experiência de não poder querer para trás. Uma perspectiva existencial que remete ao ressentimento - pois este tem sua raiz na vingança contra o tempo, contra o passar do tempo, contra a dimensão do 'foi', contra a qual a vontade nada mais pode. Ressentimento é vingança contra essa impotência, vivida sob a forma da inexorabilidade do passado, de um passado que não se pode (não se deve?) esquecer nem se pode perdoar. Em que consiste, pois, a natureza e a verdade interna do ressentimento? Ressentimento é vingança. Ora, se assim é, qual seria, então a função desse vingar-se por impotência?

Com a Psicologia de Nietzsche, aprendemos que o ressentimento é entorpecente - um narcótico. Mais precisamente: o ressentimento é anestesia, mais ou menos duradoura para sofrimentos crônicos, que assediam a consciência, ou permanecem latentes em estado de infraconsciência. Narcose cujo modo de atuação é uma descarga de afetos tônicos. No registro da representação, sentimento e desejo de vingança são traduzidos como responsabilização, o que permite e justifica uma descarga violenta de afetos hostis sobre um objeto imaginário, com a finalidade de aliviar a consciência do sofrimento.

"Pois todo sofredor busca instintivamente uma causa para seu sofrimento; mais precisamente, um agente; ainda mais especificamente um agente culpado suscetível de sofrimento - em suma, algo vivo, no qual possa sob algum pretexto descarregar seus afetos, em ato ou in effigie [simbolicamente]:

${ }^{27}$ Nietzsche, F. Fragmento póstumo nr. 16[32], primavera-verão de 188. In: Sämtliche Werke. Kritische Studienausgabe (KSA). Ed. G. Colli und M. Montinari. Berlin, New York, München: de Gruyter, DTV. 1980, vol. 12 p. 492. 
pois a descarga de afeto é para o sofredor a maior tentativa de alívio, de entorpecimento, seu involuntariamente ansiado narcótico para tormentos de qualquer espécie. Unicamente nisto, segundo minha suposição, se há de encontrar a verdadeira causação fisiológica do ressentimento, da vingança e quejandos, ou seja, em um desejo de entorpecimento da dor através do afeto-" ${ }^{28}$

Como vingança, o ressentimento é um sentir de novo - portanto, um sentimento reativo, retorno inevitável de uma indisposição crônica, reação contra uma dor, sem cessar reposta pela irreversibilidade do tempo. Ressentimento é o grilhão que mantém o ressentido cada vez mais aferrado em seu sofrimento. O ressentimento é uma modalidade culpada, biliosa, envenenadora de ascetismo. Ele adoece, destrói. É assim que o único vivido se repete como o retorno do mesmo, atando o ressentido à roda de Ixion da culpa. O ressentimento - eterno retorno da vingança e seus aparentados -, é definitivamente, a impossibilidade de acesso à inocência do vir-a- ser, que tem a forma da filosofia do amor fati.

Esclarecer-se sobre o ressentimento é superar a aversão contra o tempo, contra o passar do tempo. É fazer uso de uma terapia que combate a incapacidade de esquecer e assimilar vivências negativas. Simulacro de medicação, a vingança só aprofunda a doença, envenena a ferida que finge curar. Saúde significa, em Nietzsche, uma autoterapia capaz de livrar alguém do venenoso sentimento do ressentido, pelo restabelecimento da força plástica de esquecimento. Só então haveria a possibilidade de um horizonte do perdão.

${ }^{28}$ Nietzsche F. Genealogia da Moral. III, 15. Trad. Paulo César de Souza. São Paulo: Companhia das Letras, 1998 , p. 116. 